\title{
The Clinical Value of Serum Tau Protein in Sepsis-Associated Encephalopathy
}

\author{
Sepsisle İlişkili Ensefalopatide Serum Tau Proteininin Klinik Değeri
}

\author{
Süleyman TÜREDi,' 'Bengü DAŞDiBi,,' Süha TÜRKMEN,' Yunus KARACA,' Özgür TATLI,' \\ Ahmet MENTEŞE, ${ }^{2}$ Gürdal YILMAZ, ${ }^{3}$ Abdulkadir GÜNDÜZ' \\ 'Department of Emergency Medicine, Karadeniz Technical University Faculty of Medicine, Trabzon; \\ ${ }^{2}$ Department of Biochemistry, Karadeniz Technical University Faculty of Medicine, Trabzon; \\ ${ }^{3}$ Department of Infectious Diseases and Clinical Microbiology, Karadeniz Technical University Faculty of Medicine, Trabzon
}

\begin{abstract}
SUMMARY
\section{Objectives}

Sepsis-associated encephalopathy (SAE) is the most widespread metabolic encephalopathy, which continues to be clinically evaluated with the Glasgow Coma Scale (GCS). This study aimed to determine the clinical utility of serum tau protein as an effective and easily attainable biochemical marker of morbidity and mortality for patients with SAE.
\end{abstract}

\section{Methods}

This prospective cohort study included 70 patients admitted to the emergency department with sepsis or septic shock, who were then diagnosed with SAE based on the GCS between February 2, 2009 and July 30, 2009. Statistical analyses were performed to investigate the relationship between serum tau levels, the development of SAE and subsequent patient morbidity and mortality.

\section{Results}

Out of the total number of patients enrolled in the study, $50 \%$ received the diagnosis of SAE based on GCS upon admission. Of the patients admitted to the hospital for further observation, 2.9\% developed SAE over the course of several days using GCS criteria. Even though tau levels were higher in patients with $S A E$, there was no statistically significant difference with tau levels in patients that did not develop SAE. In addition, there were no significant correlations between tau levels, sequential organ failure assessment (SOFA) score and patient mortality.

\section{Conclusions}

Serum tau levels do not reflect brain damage and encephalopathy for SAE patients. Moreover, this protein does not correlate with patient morbidity and mortality and the SOFA score. Thus, serum tau protein cannot be utilized as a reliable biochemical marker of SAE. Further research is needed to identify effective and easily-obtainable biomarkers to supplement the GCS in SAE diagnosis.

Key words: Sepsis-associated encephalopathy; tau protein.

\section{ÖZET}

Amaç

Sepsisle ilişkili ensefalopati (SAE) en yaygın metabolik ensefalopati olup klinik olarak hâlâ Glasgow Koma Ölçeğiyle (GCS) değerlendirilmektedir. Bu çalışma SAE hastalarında morbidite ve mortalitenin etkili ve kolaylıkla test edilebilir biyokimyasal belirteci olarak tau proteinin klinik yararlıı̆̆ını belirlemeyi amaçlamıştır.

\section{Gereç ve Yöntem}

Bu prospektif kohort çalışması acil servise sepsis veya septik şokla kabul edilip, daha sonra 2 Şubat ile 30 Temmuz 2009 arasında GCS'ye göre SAE tanısı konmuş 70 hastayı kapsamaktaydı. Serum tau düzeyleriyle SAE gelişmesi ve ardından hasta morbidite ve mortalitesi arasındaki ilişkiyi araştırma amacıyla istatistiksel analizler gerçekleştirildi.

\section{Bulgular}

Çalışmaya katılan tüm hastaların \%50'si hasta kabulde GCS'ye dayanarak SAE tanısı almıştı. İleri değerlendirme için hastaneye kabul edilen hastaların \%2.9'unda GCS ölçütlerine göre birkaç gün içinde SAE gelişmişti. Tau düzeyleri SAE hastalarında daha yüksek olmasına rağmen SAE gelişmeyen hastaların tau düzeyleri arasında istatistiksel açıdan anlamlı herhangi bir farklılık yoktu. Ayrıca, tau düzeyleriyle ardışık organ yetmezliği değerlendirme skoru (SOFA) ve hasta mortalitesi arasında anlamlı korelasyonlar yoktu.

\section{Sonuç}

Serum tau düzeyleri SAE hastaları için beyin hasarı ve ensefalopati durumunu yansıtmamaktadır. Ayrıca, bu protein hasta morbidite, mortalite ve SOFA skoruyla korelasyon göstermemektedir. O halde, serum Tau proteini SAE'nin güvenilir bir biyobelirteci olarak kullanılamaz. SAE tanısında GCS'yi takviye için etkili ve kolayca elde edilebilir biyobelirteçlerin tanımlanması amacıyla ileri araştırmalara gerek vardır.

\section{Submitted (Geliş tarihi): 21.02.2013 Accepted (Kabul tarihi): 14.03.2013 Published online (Online baskı): 11.06.2013 \\ Correspondence (Illetişim): Dr. Süleyman Türedi. Karadeniz Teknik Üniversitesi Tıp Fakültesi, Acil Tıp Anabilim Dalı, 6080 Trabzon, Turkey. e-mail (e-posta): suleymanturedi@hotmail.com}




\section{Introduction}

Sepsis-associated encephalopathy (SAE) arises from a sepsis-associated systemic inflammatory response that leads to diffuse or multifocal cerebral dysfunction that is independent of structural, metabolic or direct infectious causes such as meningitis-encephalitis. ${ }^{[1]}$ Encephalopathy due to sepsis develops in more than $50 \%$ of septic patients and is correlated with greater mortality. ${ }^{[2]}$

Although the GCS is widely used in the analysis of cerebral dysfunction, it is frequently not reliable since most septic patients are sedated and on mechanical ventilation even before deteriorating neurologically. Electroencephalography, computed tomography and magnetic resonance imaging are utilized to evaluate brain dysfunction, but for these clinically tenuous patients such imaging is difficult to acquire especially if repeated imaging is indicated. Other considerations are the difficulties involved in safely transporting these patients to receive imaging and the risk of contrast-induced renal injury. ${ }^{[2]}$ As such, easily obtainable and effective biochemical markers will be extremely useful for evaluating the morbidity and mortality of SAE.

Levels of serum tau protein have been demonstrated to have diagnostic and prognostic importance in moderate to severe traumatic brain injury. ${ }^{[3]}$ In our study we endeavored to determine whether serum tau protein levels reflect the extent of brain damage and the development of encephalopathy in the evaluation of SAE patients. We strived to achieve this by investigating if serum tau levels correlated with SAE patient morbidity and mortality and with Sequential Organ Failure Assessment (SOFA) scores. In all, we strived to further advance the search for an effective biochemical marker that might complement the GCS in diagnosing SAE.

\section{Materials and Methods}

Study subjects for this prospective cohort study were comprised of $70 \mathrm{ED}$ admissions diagnosed with sepsis or septic shock between February 2, 2009 and July 30, 2009. This investigation examined the correlation between serum tau protein levels and the development, clinical course, and morbidity and mortality of SAE.

\section{Enrollment criteria}

Adult patients enrolled in the study received a diagnosis of sepsis or septic shock based on specific, commonly accepted clinical criteria. ${ }^{[4]}$ Serum tau levels were measured at the time of admission or within 24 hours of receiving the diagnosis of sepsis or septic shock. After this initial level was taken three additional levels were measured daily over 72 hours. Patients were diagnosed with SAE based on low GCS in the absence of clinical or laboratory evidence of direct brain infection. Statistical analysis was performed to determine if there is a correlation between SAE patient serum tau levels, clinical course, and mortality.

\section{Exclusion criteria}

Patients with the following encephalopathies at presentation or during monitoring were excluded from the study: acute cerebral infarction, acute cerebral hemorrhage, status epilepticus, Alzheimer's disease, hyperosmolar non-ketotic coma, diabetic ketoacidosis, recent head trauma, and direct central nervous system infection. Such cerebral pathologies were excluded because these conditions cause changes in consciousness that impede the accurate diagnosis of SAE.

\section{Data collection}

A standardized form detailing patient demographic information was completed for all subjects diagnosed with sepsis and septic shock. Upon admission or within 24 hours after receiving a diagnosis of sepsis or septic shock, a $5 \mathrm{~mL}$ blood sample was taken from patients to measure serum tau levels. Then three additional $5 \mathrm{~mL}$ blood samples were taken daily over the 72 hour period following admission or diagnosis with sepsis or septic shock. These blood samples were stored in biochemical tubes with separators and centrifuged and then transferred to Eppendorf tubes to avoid hemolysis. Specimens were preserved at -20 degrees Fahrenheit for a maximum of 5 months until all samples were examined for serum tau levels simultaneously.

Daily GCSs and SOFA scores were obtained throughout the hospitalization to determine the patient's clinical progression and severity of sepsis, respectively. The SOFA score is derived from 6 different scores that are determined by the level of impairment in respiration, coagulation, hepatic function, cardiovascular function, central nervous system function and renal function. SOFA scores range from 0 to 4 , which indicate normal function to complete malfunction, respectively. The scores are tabulated by recording the lowest value for each of the 6 categories during the first 24 hours following the diagnosis of sepsis. Note that the GCS is used to quantify the SOFA score for the central nervous system. ${ }^{[5]}$

Patients with a GCS lower than 15 in the absence of clinical or laboratory evidence of direct brain infection were diagnosed with SAE. Patients diagnosed with sepsis or septic shock were subdivided into two groups: SAE and non-SAE subjects. Patients were monitored throughout hospitalization until death or discharge. For patients that were discharged, the Glasgow Outcome Score (GOS) was measured to determine their neurological state at the end of the monitoring period. Serum tau levels were compared with SAE development and SAE patients' morbidity and mortality. 


\section{Statistical analysis}

Statistical analysis was performed using Statistical Package for the Social Sciences (SPSS) 15.0 and MedCalc 10.0 statistical program. To determine whether the data was normally distributed, the data was analyzed using the KolmogorovSmirnov test. Data are represented as the mean \pm one standard deviation (SD). Student's t-test was used to compare daily tau levels of the SAE and non-SAE groups with SOFA scores, indictors of prognosis, or GOS. Pearson correlation analysis was used for normally distributed parameters and the Spearman correlation analysis was used for data that did not follow a normal distribution. A p-value less than 0.05 was considered statistically significant.

\section{Results}

From February 2, 2009 to July 30, 2009 there were 98 patients diagnosed with sepsis or septic shock that were admitted to the university emergency medicine department. Of those patients 28 were removed from the study as they qualified for the exclusion criteria (Table 1). Study subjects' demographics including age, gender, previous diseases, other clinical diagnoses, and blood culture results are summarized in Table 2. Patients that demonstrated a GCS lower than 15 were diagnosed with SAE. Of the 37 patients diagnosed with SAE, 94.6\% were diagnosed upon admission and $5.4 \%$ were diagnosed later during their hospitalization.

Initial mean serum tau protein levels were obtained at admission from all 70 patients diagnosed with sepsis or septic shock, and these levels were organized according to whether the patients progressed to SAE or not (Table 3). Although tau levels were higher in patients that developed $\mathrm{SAE}$, there was no statistically significant difference with patients that did not develop SAE. Also there was no significant correlation between GCS and serum tau protein levels (Table 4). Thirtysix patients died throughout the course of the study, and of

Table 1. Exclusion criteria and numbers

\begin{tabular}{lc}
\hline Exclusion criteria & $\mathbf{n}$ \\
\hline Cerebral infarct & 7 \\
Alzheimer's disease & 6 \\
Hypoxic brain & 6 \\
Patients intubated on determination of sepsis & 3 \\
Brain tumor & 2 \\
Intraparenchymal hematoma & 1 \\
Subdural hematoma & 1 \\
Meningitis & 1 \\
Patient unavailable for follow-up & 1 \\
\hline
\end{tabular}

Table 2. Age, sex, previous diseases, other clinical and demographic characteristics, diagnoses, reproduction in blood culture and reproducing micro-organisms of the patients in the study

\begin{tabular}{|c|c|c|}
\hline & $\mathbf{n}$ & $\%$ \\
\hline \multicolumn{3}{|l|}{ Age } \\
\hline Mean \pm SD & $66.2 \pm 16.1$ & \\
\hline Range & $17-98$ & \\
\hline \multicolumn{3}{|l|}{ Sex } \\
\hline Male & 37 & 52.9 \\
\hline Female & 33 & 47.1 \\
\hline \multicolumn{3}{|l|}{ Previous diseases } \\
\hline Hypertension & 28 & 40 \\
\hline Diabetes mellitus & 16 & 22.9 \\
\hline Cancer & 14 & 20 \\
\hline Previous accident-surgery history & 12 & 17.1 \\
\hline Coronary insufficiency & 9 & 12.9 \\
\hline Chronic obstructive pulmonary disease & 9 & 12.9 \\
\hline Chronic kidney disease & 8 & 11.4 \\
\hline Benign prostate hypertrophy & 6 & 8.6 \\
\hline Coronary artery disease & 5 & 7.1 \\
\hline Heart valve disease & 3 & 4.3 \\
\hline Asthma & 3 & 4.3 \\
\hline Hypercholesterolemia & 3 & 4.3 \\
\hline Rheumatological diseases & 3 & 4.3 \\
\hline Chronic bronchitis & 2 & 2.9 \\
\hline Goiter & 2 & 2.9 \\
\hline Urolithiasis & 2 & 2.9 \\
\hline HBV infection & 2 & 2.9 \\
\hline Peripheral vascular disease & 1 & 1.4 \\
\hline Bronchiectasis & 1 & 1.4 \\
\hline Aortic aneurism & 1 & 1.4 \\
\hline Heart rhythm disorder & 1 & 1.4 \\
\hline Cirrhosis & 1 & 1.4 \\
\hline Osteoporosis & 1 & 1.4 \\
\hline Myelodysplastic syndrome & 1 & 1.4 \\
\hline \multicolumn{3}{|l|}{ Existing SIRS criteria } \\
\hline Respiration above $20 / \mathrm{min}$ & 55 & 78.6 \\
\hline Pulse above $90 / \mathrm{min}$ & 48 & 68.6 \\
\hline $\mathrm{PCO}_{2}$ below 32 Torr & 37 & 52.9 \\
\hline White cell count above 12000 cells $/ \mathrm{mm}^{3}$ & 36 & 51.4 \\
\hline Body temperature above 38 degrees & 19 & 27.1 \\
\hline White cell count below 4000 cells $/ \mathrm{mm}^{3}$ & 15 & 21.4 \\
\hline Body temperature below 36 degrees & 14 & 20 \\
\hline \multicolumn{3}{|l|}{ Diagnosis } \\
\hline Pneumonia & 33 & 47.1 \\
\hline Urinary tract infection & 24 & 34.3 \\
\hline Cholangitis & 6 & 8.6 \\
\hline Peritonitis & 4 & 5.7 \\
\hline Catheter infection & 3 & 4.3 \\
\hline Neutropenic fever & 3 & 4.3 \\
\hline Gastroenteritis & 3 & 4.3 \\
\hline Systemic viral infection & 2 & 2.9 \\
\hline Diabetic foot & 2 & 2.9 \\
\hline Renal abscess & 2 & 2.9 \\
\hline Acute abdomen & 1 & 1.4 \\
\hline Abdominal abscess & 1 & 1.4 \\
\hline Mesenteric vascular event & 1 & 1.4 \\
\hline Gastric perforation & 1 & 1.4 \\
\hline Soft tissue infection & 1 & 1.4 \\
\hline $\begin{array}{l}\text { Bacterial translocation secondary to } \\
\text { gastrointestinal hemorrhage }\end{array}$ & 1 & 1.4 \\
\hline Cholecystitis & 1 & 1.4 \\
\hline Empyema & 28 & 40 \\
\hline \multicolumn{3}{|l|}{ Reproduction in blood culture } \\
\hline \multicolumn{3}{|l|}{ Micro-organism reproducing in blood culture } \\
\hline Escherichia coli & 9 & 12.9 \\
\hline Staphylococcus aureus & 4 & 5.7 \\
\hline Staphylococcus epidermidis & 4 & 5.7 \\
\hline Streptococcus constellatus Ssp Constellatus & 2 & 2.9 \\
\hline Staphylococcus hominis & 1 & 1.4 \\
\hline Klebsiella pneumoniae Ssp Pneumoniae & 1 & 1.4 \\
\hline Staphylococcus haemolyticus & 1 & 1.4 \\
\hline Enterobacter cloacae & 1 & 1.4 \\
\hline Alpha hemolytic streptococcus & 1 & 1.4 \\
\hline Enterococcus faecium & 1 & 1.4 \\
\hline Providencia stuartii & 1 & 1.4 \\
\hline Coagulase negative Staphylococcus & 1 & 1.4 \\
\hline Corynebacterium jeikeium & 1 & 1.4 \\
\hline
\end{tabular}


Table 3. Mean tau protein levels in patients classified by development of sepsis-associated encephalopathy (SAE)

\begin{tabular}{|c|c|c|c|}
\hline & $\begin{array}{c}\text { Developing SAE } \\
n=37(52.9 \%)\end{array}$ & $\begin{array}{l}\text { Not developing SAE } \\
\qquad n=33(47.1 \%)\end{array}$ & $\mathbf{p}$ \\
\hline & Mean \pm SD & Mean士SD & \\
\hline Serum tau 1st day & $467.1 \pm 272.5$ & $429.9 \pm 227.1$ & 0.539 \\
\hline Serum tau 2nd day & $455.4 \pm 255.1$ & $419.9 \pm 221.8$ & 0.557 \\
\hline Serum tau 3rd day & $431.6 \pm 255.3$ & $449.3 \pm 230.1$ & 0.735 \\
\hline
\end{tabular}

those patients $91.7 \%$ were diagnosed with SAE as opposed to $8.3 \%$ that died without the SAE diagnosis $(p<0.0001)$. Analysis of the relationship between SAE and mortality revealed a positive correlation $(r=0.800, p<0.0001)$.

The mean SOFA score for SAE patients was $7.5 \pm 2.3$, which was significantly higher as compared to the SOFA score for non-SAE patients $(3.8 \pm 2.8, \mathrm{p}<0.001)$. Initial SOFA score and SAE development were positively correlated $(r=0.604$, $\mathrm{p}<0.0001)$. Also there was a significant correlation between SAE development and subsequent mortality $(r=0.487$, $\mathrm{p}<0.0001)$. No significant correlation was observed between initial SOFA score and mean tau protein levels over the three day interval following SAE diagnosis $(p=0.920 ; p=0.554$; $p=0.858$, respectively).

For the 70 patients diagnosed with sepsis or septic shock upon admission, the GOS prognostic calculation is shown in Table 5. There was no correlation determined between GOS and mean serum tau protein levels over the 72 hour period after SAE diagnosis ( $p=0.43 ; p=0.31 ; p=0.19$, respectively). Mean serum tau levels organized according to mortality due to SAE are shown in Table 6. As you can see, there are no significant differences between mean serum tau levels among those who died with SAE and those who survived with SAE.

\section{Discussion}

Tau protein is a potential biochemical marker that makes up a structural component of microtubules. This protein maintains the stability of axonal microtubules so to facilitate rapid axonal transport. ${ }^{[6]}$ Neuron integrity is compromised following traumatic brain injury and tau escapes from the intracellular compartment into the CSF and the serum. ${ }^{[7]}$ Zemlan et al. ${ }^{[7]}$ reported that initial CSF C-tau levels were a relevant predictive marker for intracranial pressure. Interestingly, C-tau was particularly sensitive in determining a positive clinical outcome for patients with severe traumatic brain injury. To the best of our knowledge there is currently no literature regarding the correlation between serum tau levels and sepsis severity, SAE development and mortality due to SAE.
SAE is a reversible central nervous system dysfunction that is classically associated with sepsis. This condition gives rise to a spectrum of clinical presentations ranging from severe agitation to coma. In a study by Sprung et al. ${ }^{[8]}$ septic encephalopathy developed in more than $50 \%$ of septic patients. Similarly, more than half of the patients in our study developed SAE. However, the mortality observed by Sprung et al. was greater for patients with SAE when compared to our investigation..$^{[8]}$

Seymour et al..$^{[9]}$ demonstrated that lower GCS scores are associated with higher SOFA scores. Jones et al. ${ }^{[10]}$ showed that hospital mortality and SOFA score parallel each other for patients presenting with severe sepsis to the ED. Thus, SOFA scores provide valuable prognostic information regarding hospital survival. It was observed that SOFA scores upon arrival to the ED were significantly higher in patients that died as compared to their counterparts that survived. Likewise, a positive correlation was determined in our patients between SOFA score and SAE development and mortality.

Our study was the first to examine the relationship between SOFA score and tau protein levels. However, no significant correlation was found between them. Additionally, we strived to determine whether it was possible to use tau as a means to gauge a patient's neurological condition at the conclusion of a patient's hospitalization. This was performed by investigating whether tau protein levels are statistically correlated with GOS, but no such relationship was

Table 4. Correlation between Glasgow Coma Score and serum tau protein levels

\begin{tabular}{lcc}
\hline Serum tau levels $(\mathbf{p g} / \mathbf{m l})$ & \multicolumn{2}{c}{ Glasgow Coma Score } \\
\cline { 2 - 3 } & $\mathbf{R}$ & $\mathbf{p}$ \\
\hline 1st day & -0.11 & 0.92 \\
2nd day & -0.08 & 0.49 \\
3rd day & 0.31 & 0.81
\end{tabular}


Table 5. Prognosis scanning of patients in the study by GOS

\begin{tabular}{|c|c|c|c|c|c|c|}
\hline \multirow[t]{2}{*}{ GOS } & \multicolumn{2}{|c|}{ SAE patients $(n=37)$} & \multicolumn{2}{|c|}{ Non-SAE patients $(n=33)$} & \multicolumn{2}{|c|}{ Total } \\
\hline & $\mathbf{n}$ & $\%$ & $\mathbf{n}$ & $\%$ & $\mathbf{n}$ & $\%$ \\
\hline 1 & 33 & 89.2 & 3 & 9.1 & 36 & 51.4 \\
\hline 2 & - & - & - & - & - & - \\
\hline 3 & 3 & 8.1 & 6 & 18.2 & 9 & 12.9 \\
\hline 4 & 1 & 2.7 & 16 & 48.5 & 17 & 24.3 \\
\hline 5 & - & - & 8 & 24.2 & 8 & 11.4 \\
\hline
\end{tabular}

Table 6. Serum Tau levels obtained in classification of SAE patients by mortality status

\begin{tabular}{lcc}
\hline Mean serum tau levels $(\mathbf{p g} / \mathbf{m l})$ & $\begin{array}{c}\text { Living patients } \\
(\text { Mean } \pm \text { SD) }\end{array}$ & $\begin{array}{c}\text { Fatal patients } \\
\text { (Mean } \pm \text { SD) }\end{array}$ \\
\hline 1st day $^{\mathrm{a}}$ & $420.2 \pm 218.2$ & $488.4 \pm 283.4$ \\
2nd day ${ }^{\mathrm{b}}$ & $425.9 \pm 243.7$ & $486.3 \pm 267.4$ \\
3rd day & $313.2 \pm 57.4$ & $398.6 \pm 207.1$ \\
\hline
\end{tabular}

$a: p=0.31 ; b: p=0.25 ; c: p=0.41$.

established. Furthermore, no significant correlation was determined between survivors and non-survivors among patients developing SAE and serum tau protein levels. This suggests that serum tau levels cannot be used for prognostic purposes to reflect SAE patient mortality and neurological status among survivors.

Easily obtainable and effective biochemical markers will be very useful in predicting the morbidity and mortality of SAE. Another potential biomarker is an astrocyte protein that is responsible for intracellular calcium homeostasis called S100B. It has been suggested that the presence of S-100B in the serum, urine or cerebrospinal fluid (CSF) indicates glial cell and blood-brain barrier damage. In particular, increased serum levels of this protein has been reported after cardiac arrest, traumatic brain injury, cardiac bypass surgery, perinatal asphyxia and other central nervous system injuries. ${ }^{[1]}$

Dimopoulou et al. demonstrated that serum S-100B levels can predict the progression to brain death for children with brain injury. ${ }^{[11]}$ An additional putative biochemical marker for SAE is neuron-specific enolase (NSE), which is a glycolytic enzyme localized in neurons. NSE has been utilized as a marker of neurological injury in trauma, cardiac arrest and other neurological disorders. ${ }^{[11]}$ In a study of 170 adults with sepsis or septic shock, Nguyen et al. showed that there were high levels of both S-100B and NSE in $42 \%$ and $53 \%$ of the patients, respectively. This study also established that both markers were positively correlated with mortality. ${ }^{[2]}$ Weigand et al. ${ }^{[12]}$ reported that serum NSE levels possess high specificity and sensitivity in predicting mortality for severe sepsis in the intensive care unit. Overall, there are several possibilities for putative biomarkers that may serve as prognostic indicators for the clinical progression of SAE.

\section{Limitations}

Because this was the first study investigating tau as a potential biomarker for the morbidity and mortality associated with SAE, there were several limitations inherent in our research design. Primarily, the investigation was conducted with a small sample size. More importantly, patients were triaged directly from the ED regardless of their preexisting health conditions that may have influenced the outcomes of this study. As such we recommend that larger multicenter studies be performed in other clinical contexts including intensive care units in order to draw a more generalizable conclusion regarding the association between serum tau and SAE.

This study determined that serum tau levels do not reflect the extent of brain damage and the development of SAE. As such tau cannot be used as a supplementary biological indicator to the GCS in diagnosing SAE. Furthermore, there is no correlation between tau levels and SOFA score and SAE morbidity and mortality. Nevertheless, this was a prelimi- 
nary study with several limitations and so the validity of our results must be further examined with larger multicenter cohort studies.

\section{Conflict of Interest}

The authors declare that there is no potential conflicts of interest.

\section{References}

1. Piazza O, Russo E, Cotena S, Esposito G, Tufano R. Elevated S100B levels do not correlate with the severity of encephalopathy during sepsis. Br J Anaesth 2007;99:518-21. [CrossRef]

2. Nguyen DN, Spapen H, Su F, Schiettecatte J, Shi L, HachimiIdrissi S, Huyghens L. Elevated serum levels of S-100beta protein and neuron-specific enolase are associated with brain injury in patients with severe sepsis and septic shock. Crit Care Med 2006;34:1967-74. [CrossRef]

3. Ma M, Lindsell CJ, Rosenberry CM, Shaw GJ, Zemlan FP. Serum cleaved tau does not predict postconcussion syndrome after mild traumatic brain injury. Am J Emerg Med 2008;26:763-8.

4. Dellinger RP, Levy MM, Rhodes A, Annane D, Gerlach H, Opal $\mathrm{SM}$, et al. Surviving sepsis campaign: international guidelines for management of severe sepsis and septic shock: 2012. Crit Care Med 2013;41:580-637. [CrossRef]

5. Wehler M, Kokoska J, Reulbach U, Hahn EG, Strauss R. Shortterm prognosis in critically ill patients with cirrhosis assessed by prognostic scoring systems. Hepatology 2001;34:255-61.
6. Shahani N, Brandt R. Functions and malfunctions of the tau proteins. Cell Mol Life Sci 2002;59:1668-80. [CrossRef]

7. Zemlan FP, Jauch EC, Mulchahey JJ, Gabbita SP, Rosenberg WS, Speciale SG, et al. C-tau biomarker of neuronal damage in severe brain injured patients: association with elevated intracranial pressure and clinical outcome. Brain Res 2002;947:131-9. [CrossRef]

8. Sprung $\mathrm{CL}$, Peduzzi PN, Shatney $\mathrm{CH}$, Schein RM, Wilson MF, Sheagren JN, et al. Impact of encephalopathy on mortality in the sepsis syndrome. The Veterans Administration Systemic Sepsis Cooperative Study Group. Crit Care Med 1990;18:8016. [CrossRef]

9. Seymour CW, Band RA, Cooke CR, Mikkelsen ME, Hylton J, Rea TD, et al. Out-of-hospital characteristics and care of patients with severe sepsis: A cohort study. J Crit Care 2010;25:55362. [CrossRef]

10. Jones AE, Trzeciak S, Kline JA. The Sequential Organ Failure Assessment score for predicting outcome in patients with severe sepsis and evidence of hypoperfusion at the time of emergency department presentation. Crit Care Med 2009;37:1649-54. [CrossRef]

11. Hsu AA, Fenton $K$, Weinstein S, Carpenter J, Dalton H, Bell MJ. Neurological injury markers in children with septic shock. Pediatr Crit Care Med 2008;9:245-51. [CrossRef]

12. Weigand MA, Volkmann $M$, Schmidt $H$, Martin $E$, Böhrer $H_{\text {, }}$ Bardenheuer HJ. Neuron-specific enolase as a marker of fatal outcome in patients with severe sepsis or septic shock. Anesthesiology 2000;92:905-7. [CrossRef] 